\title{
"Organization and effectiveness of marketing management of agricultural commodity producers under non-cooperative marketing: the experience of Ukraine"
}

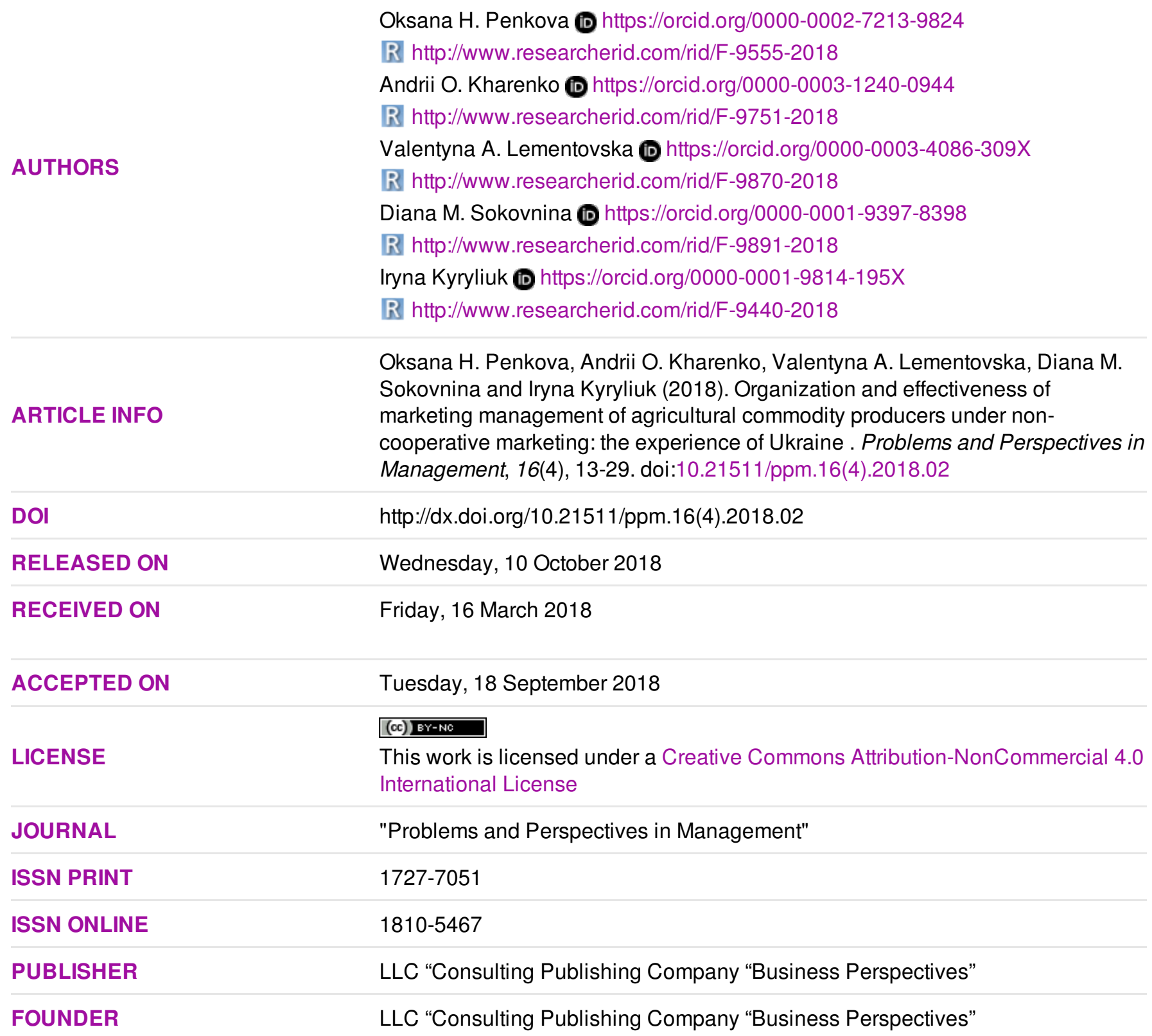

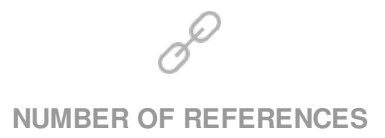

26
NUMBER OF FIGURES

2

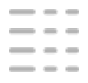

NUMBER OF TABLES

11

(C) The author(s) 2023. This publication is an open access article. 


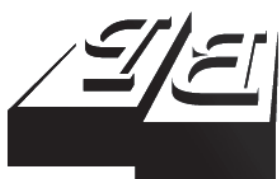

BUSINESS PERSPECTIVES

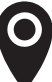

LLC “CPC "Business Perspectives" Hryhorii Skovoroda lane, 10, Sumy, 40022, Ukraine

www.businessperspectives.org

Received on: $16^{\text {th }}$ of March, 2018 Accepted on: $18^{\text {th }}$ of September, 2018

(C) Oksana H. Penkova, Andrii O. Kharenko, Valentyna A. Lementovska, Diana M. Sokovnina, Iryna M. Kyryliuk, 2018

Oksana H. Penkova, Doctor of Economics, Associate Professor, Department of Marketing, Uman National University of Horticulture, Ukraine.

Andrii O. Kharenko, Ph.D. (Economics), Associate Professor, Department of Marketing, Uman National University of Horticulture, Ukraine.

Valentyna A. Lementovska, Ph.D. (Economics), Associate Professor, Department of Marketing, Uman National University of Horticulture, Ukraine.

Diana M. Sokovnina, Ph.D. (Economics), Associate Professor, Department of Marketing, Uman National University of Horticulture, Ukraine.

Iryna M. Kyryliuk, Ph.D. (Economics), Associate Professor, Department of Tourism, Hotel and Restaurant Activities, Pavlo Tychyna Uman State Pedagogical University, Ukraine.

\section{(ㄷ)(1) $(8)$}

This is an Open Access article, distributed under the terms of the Creative Commons Attribution-NonCommercial 4.0 International license, which permits re-use, distribution, and reproduction, provided the materials aren't used for commercial purposes and the original work is properly cited.
Oksana H. Penkova (Ukraine), Andrii O. Kharenko (Ukraine),

Valentyna A. Lementovska (Ukraine), Diana M. Sokovnina (Ukraine),

Iryna M. Kyryliuk (Ukraine)

ORGANIZATION AND

EFFECTIVENESS OF MARKETING MANAGEMENT OF AGRICULTURAL COMMODITY PRODUCERS UNDER NON-COOPERATIVE MARKETING: THE EXPERIENCE OF UKRAINE

\begin{abstract}
Under reducing domestic demand for food in Ukraine and increasing dependence on the world food market, a significant part of quasi-price rent from its sale is assigned by intermediary exporters, thus reducing the welfare of domestic commodity producers and consumers. To mitigate this negative effect, it is necessary to have a carefully designed marketing business strategy. The purpose of this article is to summarize the practice of using the main elements of the marketing complex, analyze the effective management of marketing activities of agricultural producers in Ukraine and determine the main directions for increasing its effectiveness by establishing marketing relations for the product supply. Given the large area of Ukraine and the complexity to obtain monographic data that are not subject to monitoring by the State Statistics Service, the study was conducted using agricultural enterprises of the typical agricultural district, namely Khrystynivka district of Cherkasy region (Ukraine) as an example. It is revealed that the use of marketing tools by agricultural enterprises is limited due to the specifics of commodity products and the managers' focus on short-term business goals. The analysis of forming and realizing the marketing complex of the district enterprises using the monographic method has shown that enterprises systematically use only elements such as commodity policy and distribution policy, while relying exclusively on retrospective marketing data. Significant increase in the return on marketing costs in the short term can only be achieved if formal or informal associations of commodity producers are formed on a functional-territorial basis. This will create a scale effect and allow each member to reduce transaction costs and get an additional premium. It is proved that while conducting administrative-territorial reform in Ukraine, it is most appropriate to form such associations within the boundaries of the united territorial communities.
\end{abstract}

\section{Keywords}

effectiveness, marketing complex, marketing activity, marketing strategies, marketing activity management,

JEL Classification agrarian marketing

L10, M31, Q13

\section{INTRODUCTION}

Agriculture plays an essential role in the Ukrainian economy development. Over the past three years, about $17 \%$ of all employed in the economy accounted for agriculture, generating about $12 \%$ of the country's GDP and providing over $30 \%$ of export revenues. But the profitability of agricultural enterprises even within the same district is significantly different, which is largely due to the level of organization of their management and marketing performance management. State Statistics Service of Ukraine data confirm this statement. In the first quarter of 2018, according to the results of the survey among agricultural enterprises managers, the factors inhibiting their activities were: 
labor shortage - 3\%; lack of materials and equipment - 3\%; insufficient demand - $9 \%$; weather conditions - 26\%; financial constraints - 28\%; nothing inhibits - 34\% (State Statistics Service of Ukraine, 2018). Of course, the different influence of these factors is determined by the scale of enterprises' activity, their specialization, the degree of the product portfolio diversification, fluctuations of market prices for products, etc. But of all this is in the strategic and tactical marketing management decisions area.

If, within one country, the natural and climatic conditions vary considerably, and, as a consequence, the specialization of agricultural enterprises may differ to a great extent, then it is similar in the same area in a number of farms. This allows for comparing their relative marketing performance and determine the strategies to improve it.

\section{LITERATURE REVIEW}

The formation and development of marketing theory have led to the gradual transfer of its postulates to the agricultural enterprise activities in developed countries. However, according to Meulenberg (1986), "the evolution of agribusiness marketing approaches to marketing management was somewhat different for the following reasons: individual farmers have limited contacts with the end user and limited ability to manage the marketing mix (price, product, advertising and distribution); agricultural marketing often works within the institutional and technical constraints imposed by government policies; strong attachment of agrarian marketing to economic theory as its scientific background" (Meulenberg, 1986).

Kohls and Uhl (2002) scrutinize the issue of food products marketing organization. In their study, based on American experience, the main problems of organizing marketing for agricultural products from the manufacturer to the final customer as a whole and for certain types of products are highlighted. We cannot but agree with Opara (2003) that the emphasis of agrarian competition shifts from business to integral chains, thus allowing producers and consumers to monitor the quality and safety of food products. Commodity associations that can unite not only producers, but also intermediaries and consumers play an important role in this process. Their role in food marketing has been analyzed by Cadilhon Jo and Dedieu Marie-Sophie (2011). Gallego-Alvarez, Prado-Lorenzo, RodríguezDomínguez, and García-Sánchez (2010), using data from 120 European companies, demonstrated that the environmental and social responsibility policy should be built into marketing strategy of the company, which seeks to increase its share price.
Carillo, Caracciolo, and Cembalo (2017) have proven the importance of coordinating the efforts in shaping marketing sales policies. Using 2008-2011 panel data on Italian farm businesses that specialize in growing durum wheat, the authors conclude that participating in vertically coordinated associations provides farmers with increased sales profitability, or so-called "coordination awards" (Carillo, Caracciolo, \& Cembalo, 2017).

Marketing activities of commodity producers can be coordinated by so-called marketing boards, or those controlled mainly by commodity producers or by the government. The motivation for the government marketing boards creation could be, for example, to protect the interests of (urban) consumers or stimulate exports. They flourished in the 20th century both in developed and developing countries. Beginning in the mid-1980s, their numbers have fallen under the pressure of internal liberalization and international trade rules that increasingly concern agriculture (Barrett \& Mutambatsere, 2008). However, according to Canadian experience of the establishment and operation of non-governmental milk marketing boards, or "self-regulated, hybrid institutions run by producers but requiring government intervention ... that, historically, envision a wider function than simply increasing the rent of producers" (Annie Royer, 2008), in the current situation, they can also help increase marketing performance of agricultural commodity producers.

Chand (2012) writes about the role of the state in stimulating the development of marketing infrastructure of the agrarian market, in smoothing out the negative impact of market price fluctuations on the world food markets on national producers and consumers. The author used India as an example, 
which, like Ukraine, is a net exporter of agricultural products (Chand, 2012).

One can agree with Chemerys (2017) who emphasizes the negative impact of the underdeveloped marketing infrastructure of the Ukrainian agrarian market on the interaction of agricultural commodity producers. But the course taken in Ukraine to liberalize market relations has been reflected in the almost complete removal of the state from the support of domestic farmers, so that the presence of competition will be an impetus for business entities improvement and modernization. Therefore, Larina (2008), Stepanova, Horbas, and Davydova (2017) emphasize the advantages of using agribusiness marketing strategies for diversification as a means of minimizing the risks of activities under such conditions.

Soloviov (2008), Larina (2008), Ulianchenko and Kosenko (2008) believe that in order to construct a real-world system of agromarketing in Ukraine, a horizontal or vertical union of players in the market is needed on cooperative (Larina, 2008; Soloviov, 2008) or cluster basis (Ulianchenko \& Kosenko, 2014). However, the theoretical model of Agbo, Rousselière, and Salanié (2015) shows that marketing co-operatives can have anticompetitive impact on the direct sales market. And marketing effectiveness in cooperative and non-cooperative marketing channels and production profits may not be very different (Sarker \& Ghosh, 2010).

Literature on the problems of the agrarian marketing organization shows that in developed countries with the established agricultural markets, marketing co-operation or coordination of commodity producers are prevalent. In Ukraine, cooperative marketing at this stage has not become widespread, and marketing activities organization is different and has its own characteristics. Although these publications outline possible promising directions for the agrarian marketing development in Ukraine in the medium to long term, they do not answer the question how to improve marketing activities management of agricultural enterprises in Ukraine, taking into account existing resource and institutional constraints in the short term.

For most small Ukrainian farmers, today's problems that are inherent in the agricultural commod- ity producers in developing countries continue to be relevant. Namely, farmers usually decide on the product quantity and collect it before finding out at what price it can be sold. This uncertainty in prices makes it difficult for farmers to make optimal decisions about production and harvesting. Additionally, farmers are often limited in choosing where to sell their harvest: some farmers sell only to intermediaries pulling up at the farm gate, others can only sell through their local market (Ferreira, Goh, \& Valavi, 2017). The decision making also depends on the product quality (low quality of used seeds and fertilizers cause low quality of final products); on the product transportation (many rural areas do not have the proper roads, and this creates barriers in transporting the agricultural products to the market); and on the lack of warehouses (Kiruthiga, Karthi, \& Daisy, 2015).

\section{RESEARCH OBJECTIVE}

The purpose of the article is to generalize practical aspects of organization, analyze the non-cooperative marketing performance of agricultural producers in Ukraine and determine the main ways to increase its effectiveness.

\section{RESEARCH METHODOLOGY}

Analysis, system approach, dialectical method of scientific knowledge, fundamental provisions of modern economic theory, marketing, strategic management concept, scientific works of leading academic economists, devoted to the problems of marketing activity management of agricultural commodity producers, make the methodological basis of the research.

To achieve the purpose of the article, theoretical and empirical methods of scientific knowledge were used: analysis - to determine the economic efficiency of marketing activities management of enterprises; grouping and comparing statistical data - to determine the place and role of the economic entities under consideration in the total population of the industry; monographic method to study the peculiarities of marketing activities of individual enterprises; and abstract-logical method - to summarize the study results. 


\section{RESULTS}

The choice for a separate district of Cherkasy region (Ukraine) as a research base is because the region is predominantly agrarian. Thus, using only $3.5 \%$ of the total national agricultural land, in 2016, it produced $5.9 \%$ of gross agricultural products and ranked third among the regions of Ukraine in terms of the production (Statistical Book, 2016). Khrystynivka district is a typical agricultural area of the region and all its agricultural enterprises predominantly use the same objects of logistic infrastructure.

Marketing effectiveness should be studied based on its main components. Most agricultural producers, as a rule, limit marketing activities to the formation and adjustment of commodity policies.

Farms in Khrystynivka district produce a large range of products (Table 1), which has a width of a commodity mix of 7, and a length of 4.14. Crop farming is represented by a greater number of commodity items, 22, the overwhelming number of which is produced by almost all the objects under study. Fruit, vegetables and sugar beet, which are produced by one enterprise each, are the exception. Livestock products are produced by $2 / 3$ farms in the region, giving preference to cattle breeding. Pig and sheep farming are practiced by only two farms each, using the bulk of products for their own needs (food for workers).

Via $A B C$ analysis, the products priority of the studied commodity producers in the region is assessed in terms of share of the implementation of assortment units in the total sales according to the 2012-2016 averaged data (Table 2).

According to Table 2, Group A includes sunflower seeds, milk, grain maize and wheat. These categories account for $22 \%$ in the nomenclature, and bring $84 \%$ income to farms. Intermediate positions (B) include cattle, rape plant and barley growth. The other $60 \%$ of the range is a by-products group $(\mathrm{C})$.

The quality of the products produced is one of the key points in any enterprise commodity policy. Its high level provides farms with a certain level of competitiveness in the market. Commodity producers of Khrystynivka district used the current national standards for the types of products they produce. The analysis of the current state of agricultural products standardization shows that there are 566 national standards in force in the country, of which $64.8 \%$ meet the international or European standards. There are 367 current intergovernmental standards, only $4.3 \%$ of which were harmonized (Humeniuk, 2014).

Prices for products of agricultural enterprises are formed under the influence of supply and demand for it. That is why, while having information about their current correlation, it is possible to respond promptly to predicted changes and, accordingly, to sell products with greater profit. In addition, their export-oriented types are affected by the ap-

Table 1. Agricultural products nomenclature of the enterprises of Khrystynivka district, Cherkasy region (main activity)

Source: Calculated based on the Statistical Yearbook of Ukraine.

\begin{tabular}{|c|c|c|c|c|c|c|c|}
\hline \multirow{12}{*}{ 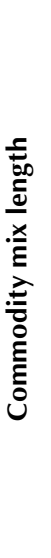 } & \multicolumn{7}{|c|}{ Commodity mix width } \\
\hline & Grain & $\begin{array}{l}\text { Oil crops } \\
\text { (seeds) }\end{array}$ & $\begin{array}{l}\text { Vegetables } \\
\text { and fruit }\end{array}$ & $\begin{array}{l}\text { Other plant } \\
\text { products }\end{array}$ & $\begin{array}{c}\text { Meat (live } \\
\text { weight basis) }\end{array}$ & Milk & $\begin{array}{c}\text { Other } \\
\text { animal } \\
\text { products }\end{array}$ \\
\hline & 1. Winter wheat & 1. Sunflower & 1. Cucumbers & 1. Sugar beet & 1. Big cattle & 1. Pure milk & 1. Honey \\
\hline & 2. Spring wheat & 2. Rape plant & 2. Tomatoes & 2. Seed grains & 2. Pigs & - & 2. Rearers \\
\hline & 3. Winter barley & 3. Soy & 3. Apples & 3. Silage & 3. Sheep & - & 3. Dung \\
\hline & 4. Spring barley & - & 4. Pears & 4. Haylage & - & - & - \\
\hline & 5. Grain maize & - & - & 5. Bran & - & - & - \\
\hline & 6. Pea & - & - & - & - & - & - \\
\hline & 7. Buckwheat & - & - & - & - & - & - \\
\hline & 8. Millet & - & - & - & - & - & - \\
\hline & 9. Oats & - & - & - & - & - & - \\
\hline & 10. Rye & - & - & - & - & - & - \\
\hline
\end{tabular}


Table 2. Results of the $A B C$ analysis of the commodity assortment of agricultural enterprises of Khrystynivka district, Cherkasy region

Source: Calculated based on the Statistical Yearbook of Ukraine.

\begin{tabular}{|c|c|c|c|c|}
\hline Commodity & Return, UAH thou* & Share in return, $\%$ & Share rising, $\%$ & ABC group \\
\hline Sunflower seeds & $87,857.9$ & 24.72 & 24.72 & $A$ \\
\hline Milk & $87,089.5$ & 24.51 & 49.23 & A \\
\hline Grain maize & $80,463.1$ & 22.66 & 71.89 & A \\
\hline Wheat & 43,575 & 12.26 & 84.15 & A \\
\hline Big cattle meat (live weight) & $13,873.8$ & 3.9 & 88.05 & B \\
\hline Rape plant & $13,036.2$ & 3.67 & 91.72 & B \\
\hline Barley & $11,217.5$ & 3.16 & 94.88 & $B$ \\
\hline Soy & $5,823.5$ & 1.64 & 96.52 & C \\
\hline Pig (live weight) & $3,005.4$ & 0.85 & 97.37 & C \\
\hline Other animal products & $2,440.5$ & 0.69 & 98.06 & C \\
\hline Other vegetable products & $2,186.2$ & 0.62 & 98.68 & C \\
\hline Services & $1,690.9$ & 0.48 & 99.16 & C \\
\hline Pea & $1,042.8$ & 0.29 & 99.45 & C \\
\hline Field vegetables & 879.4 & 0.25 & 99.7 & C \\
\hline Fruit & 426.6 & 0.12 & 99.82 & C \\
\hline Sugar beet & 303.8 & 0.09 & 99.91 & C \\
\hline Buckwheat & 252.8 & 0.07 & 99.98 & C \\
\hline Rye & 58.9 & 0.02 & 100 & C \\
\hline Total & 355376.3 & 100 & $x$ & $x$ \\
\hline
\end{tabular}

Note: * Average return for the period 2012-2016.

propriate international market environment (first of all, it concerns grains and oilseeds). A separate aspect of pricing is the fact that the overwhelming amount of grains and oilseeds and significant proportion of animal meat is marketed through intermediary structures that have their own business interests. It is also necessary to consider the price elasticity factor. In the case when an agricultural enterprise sells products to end consumers, there is a seasonal price fluctuation, another feature that has a significant impact on pricing. In general, the price factor is crucial for farms in the process of selling agricultural products. It directly affects their profit, and accordingly, the technical and technological updating of the production process.

Table 3 indicates that in recent years, prices for agricultural products have increased significantly. The main factor that has led to this situation is not the market environment, but the common inflationary processes in Ukraine. However, in terms of product line groups, growth occurred at different rates. Thus, prices for export-oriented products (grains and oilseeds) increased 2.5-3 times (in this case, in addition to the increase in the cost of purchase resources, the effect of the exchange rate difference between the hryvnia and the US dollar was observed), for the domestic market goods, an increase of 1.3-1.8 times took place.

The sale to "other business entities" (the organizations are included that purchase products for further resale, including grain traders) was the main channel for selling grain crops for agricultural enterprises in Khrystynivka district (Table 4). The share of this type of distribution channel varies for different crops, but it is over $90 \%$ in recent years. Since for two decades, stock exchange trade has not been properly developed in Ukraine, the lion's share of grain is being sold through other market channels. They are characterized by disorganization, volume and pricing opacity.

For the vast majority of business entities in the region under study, sales contracts are the main documents certifying sales agreements, the content and design of which are often undefined, which leads to difficulties in resolving disputes. Part of the grain is sold without such contracts conclusion. The vast majority of producers in the region do not have necessary grain storage facilities. In addition, they are low-level equipped with appropriate cleaning and drying machines, which adversely affects the bringing of the grain to the 
Table 3. Selling price dynamics for products of agricultural enterprises of Khrystynivka district, Cherkasy region, UAH per 1 centner

Source: Compiled based on Statistical Yearbook of Ukraine.

\begin{tabular}{|c|c|c|c|c|c|c|c|}
\hline \multirow{2}{*}{ Products } & \multirow{2}{*}{2012} & \multirow{2}{*}{2013} & \multirow{2}{*}{2014} & \multirow{2}{*}{2015} & \multirow{2}{*}{2016} & \multicolumn{2}{|c|}{$2016(\%)$ till } \\
\hline & & & & & & 2012 & 2015 \\
\hline Wheat & 147.06 & 123.10 & 165.56 & 292.43 & 306.23 & 208.2 & 104.7 \\
\hline Rye & 138.23 & 92.08 & 350.00 & - & 326.53 & 236.2 & - \\
\hline Buckwheat & 380.02 & 206.73 & 213.40 & 899.08 & $1,320.39$ & 347.5 & 146.9 \\
\hline Grain maize & 166.65 & 131.88 & 141.97 & 330.27 & 353.19 & 211.9 & 106.9 \\
\hline Barley & 164.51 & 143.27 & 165.58 & 303.05 & 287.78 & 174.9 & 95.0 \\
\hline Pea & 208.78 & 217.34 & 373.89 & 353.61 & 605.37 & 290.0 & 171.2 \\
\hline Sunflower seeds & 358.69 & 308.21 & 393.76 & 828.76 & 882.89 & 246.1 & 106.5 \\
\hline Rape plant & 343.59 & 301.06 & 379.25 & 666.78 & $1,005.09$ & 292.5 & 150.7 \\
\hline Soy & 331.39 & 321.68 & 434.87 & 753.62 & 864.06 & 260.7 & 114,7 \\
\hline Sugar beet & 36.12 & - & - & - & 70.77 & 195.9 & - \\
\hline Field vegetables & 298.08 & 349.23 & 413.47 & 396.39 & 212.13 & 71.2 & 53.5 \\
\hline Fruit & 326.25 & 242.27 & 125.35 & 273.44 & 415.12 & 127.1 & 151.8 \\
\hline Big cattle meat (live weight) & 1174.72 & 963.31 & $1,328.90$ & $2,177.64$ & $2,147.65$ & 182.8 & 98.6 \\
\hline Pig (live weight) & 1481.04 & $1,274.56$ & $1,270.00$ & $2,132.63$ & $2,010.26$ & 135.7 & 94.3 \\
\hline Milk & 278.39 & 355.96 & 402.99 & 476.23 & 590.24 & 212.0 & 123.9 \\
\hline
\end{tabular}

necessary basic conditions. All this leads to the fact that many farms are forced to sell grain during harvesting at reduced prices in cash to grain traders' representatives, without spending money on grain transportation and processing. The availability of loan commitments for the future harvest from the past or the beginning of the current year was another factor affecting the sale of part of the production during the harvest period. To a certain extent, a significantly higher level of purchasing prices contributed to the focus on this channel.

The directions indicated in Table 4 are partly regulated grain delivery channels. At the beginning

Table 4. The structure of channels for selling grain crops by agricultural enterprises of Khrystynivka district, Cherkasy region

Source: Compiled based on Statistical Yearbook of Ukraine.

\begin{tabular}{|c|c|c|c|c|c|c|}
\hline \multirow[b]{2}{*}{ Year } & \multirow[b]{2}{*}{ Products } & \multicolumn{5}{|c|}{ Marketing channels } \\
\hline & & $\begin{array}{l}\text { Processing } \\
\text { enterprises }\end{array}$ & $\begin{array}{l}\text { To the population } \\
\text { in the payment for } \\
\text { work }\end{array}$ & $\begin{array}{c}\text { To shareholders in } \\
\text { compensation of } \\
\text { rental payment }\end{array}$ & $\begin{array}{c}\text { On the market, } \\
\text { through own } \\
\text { stores }\end{array}$ & $\begin{array}{l}\text { To other } \\
\text { business } \\
\text { entities }\end{array}$ \\
\hline \multirow{6}{*}{2012} & Wheat & 8.7 & 8.7 & 11.1 & 1.5 & 70.0 \\
\hline & Rye & - & - & - & 1.5 & 98.5 \\
\hline & Buckwheat & - & - & 4.9 & 13.0 & 82.1 \\
\hline & Grain maize & 3.3 & 0.1 & 2.4 & - & 94.2 \\
\hline & Barley & - & 0.1 & 2.2 & 1.0 & 96.7 \\
\hline & Pea & - & - & - & 0.3 & 99.7 \\
\hline \multirow{6}{*}{2014} & Wheat & - & 6.3 & 8.5 & - & 85.2 \\
\hline & Rye & - & - & - & - & 100.0 \\
\hline & Buckwheat & - & 0.5 & - & - & 99.5 \\
\hline & Grain maize & - & 1.1 & 4.5 & - & 94.4 \\
\hline & Barley & - & 0.8 & 9.6 & - & 89.6 \\
\hline & Pea & - & 0.1 & - & - & 99.9 \\
\hline \multirow{6}{*}{2016} & Wheat & 0.3 & 4.0 & 3.0 & 1.0 & 91.8 \\
\hline & Rye & - & - & - & - & 100.0 \\
\hline & Buckwheat & - & - & - & - & 100.0 \\
\hline & Grain maize & - & 0.5 & 0.9 & 0.1 & 98.5 \\
\hline & Barley & - & 1.0 & 7.2 & 0.6 & 91.2 \\
\hline & Pea & - & - & - & - & 100.0 \\
\hline
\end{tabular}


Table 5. The structure of oilseed crops sales channels by agricultural enterprises of Khrystynivka district, Cherkasy region

Source: Compiled based on Statistical Yearbook of Ukraine.

\begin{tabular}{|c|c|c|c|c|c|c|}
\hline \multirow[b]{2}{*}{ Year } & \multirow[b]{2}{*}{ Products } & \multicolumn{5}{|c|}{ Marketing channels } \\
\hline & & $\begin{array}{l}\text { Processing } \\
\text { enterprises }\end{array}$ & $\begin{array}{l}\text { To the population } \\
\text { in the payment for } \\
\text { work }\end{array}$ & $\begin{array}{l}\text { To shareholders in } \\
\text { compensation of } \\
\text { rental payment }\end{array}$ & $\begin{array}{c}\text { On the } \\
\text { market, } \\
\text { through own } \\
\text { stores }\end{array}$ & $\begin{array}{l}\text { To other } \\
\text { business } \\
\text { entities }\end{array}$ \\
\hline \multirow{3}{*}{2012} & Sunflower seeds & 6.2 & - & 1.5 & 0.1 & 92.2 \\
\hline & Soy & - & - & - & 1.2 & 98.8 \\
\hline & Rape plant & - & 1.9 & - & - & 98.1 \\
\hline \multirow{3}{*}{2014} & Sunflower seeds & 1.9 & - & 1.1 & - & 97.0 \\
\hline & Soy & - & - & - & - & 100.0 \\
\hline & Rape plant & - & - & - & - & 100.0 \\
\hline \multirow{3}{*}{2016} & Sunflower seeds & 12.6 & - & 0.5 & 0.1 & 86.8 \\
\hline & Soy & - & - & - & - & 100 \\
\hline & Rape plant & 33.8 & - & - & - & 66.2 \\
\hline
\end{tabular}

of the period investigated, significant volumes of wheat and maize were sold to the population for the payment of salaries and to shareowners as rental payments. However, in the future, the proportion of these channels began to steadily decrease in favor of business entities. This is explained by the fact that the number of shareholders who live in rural areas, and, consequently, keep the subsistence farming, decreases each year mainly due to demographic factors, and those living in cities prefer not the natural but the monetary terms of the rent. The current marketing channel for cereals is sale on the market or through own stores. It is interesting that farms, at the request of processing enterprises, undertake to produce a specified quantity of cereal grains, and the other party - to purchase it at a certain price.

The structure of oilseed crops produced by agricultural enterprises in Khrystynivka district (Table 5) shows the domination of sales to "other economic entities" with a gradual increase in cooperation between commodity producers and processing enterprises. All crops belonging to this group are export-oriented, but if rape plant and soybeans were found to be mainly in the form of grain abroad, then sunflower seeds are processed products. In recent years, Ukraine has significantly increased the capacity of the oil and fat industry, and especially rape, since the processed products on the international markets are much more profitable. This fact has positively influenced the price offer of traders to agricultural producers, since domestic processing enterprises need more and more raw materials every year. The situation with documenting the facts of buying and selling oilseeds is similar to that of cereals.

Sugar beets and field vegetables are fully sold to targeted processing enterprises. So, beets are sold to LLC Illinetskyi Sugar Plant, while vegetables (cucumbers and tomatoes) are sold to the Haisyn Canning Factory. On the contrary, fruit products are sold in full to retail businesses located in large cities.

Unlike crop products, processing companies are the key selling channel for livestock products (Table 6). Thus, traditionally, milk produced by agricultural enterprises of Khrystynivka district is practically sold in full at PJSC "Khrystynivskyi Dairy Plant" (Khrystynivka, Cherkasy region) and LLC "Lustdorf" (production facilities are located in Illinka, Vinnytsia region). When forming the price for milk raw materials to sell to the processing enterprises, the time for milk sale takes a considerable pressure. Production of live weight of big cattle meat by farms in the region under study is derived from dairy cattle breeding. The given products are purchased by meat processing enterprises of Cherkasy, Vinnytsia and some other regions almost in full. A small number is sold to business entities (private entrepreneurs working in the food field or retail trade). It is mainly represented by animals that need to be urgently sold because of their injuries. The bulk of live weight of pigs is also sold to the processing enterprises. However, when it comes to big cattle, it is a large business entity, while in the case of pigs, there are processing shops of a local level. In 2014, produc- 
Table 6. The structure of livestock products sales channels by agricultural enterprises of Khrystynivka district, Cherkasy region

Source: Compiled based on Statistical Yearbook of Ukraine.

\begin{tabular}{|c|c|c|c|c|c|c|}
\hline \multirow[b]{2}{*}{ Year } & \multirow[b]{2}{*}{ Products } & \multicolumn{5}{|c|}{ Marketing channels } \\
\hline & & $\begin{array}{l}\text { Processing } \\
\text { enterprises }\end{array}$ & $\begin{array}{l}\text { To the population } \\
\text { in the payment for } \\
\text { work }\end{array}$ & $\begin{array}{l}\text { To shareholders in } \\
\text { compensation of } \\
\text { rental payment }\end{array}$ & $\begin{array}{c}\text { On the } \\
\text { market, } \\
\text { through own } \\
\text { stores }\end{array}$ & $\begin{array}{c}\text { To other } \\
\text { business } \\
\text { entities }\end{array}$ \\
\hline \multirow{3}{*}{2012} & $\begin{array}{l}\text { Big cattle meat (live } \\
\text { weight) }\end{array}$ & 89.7 & 2.1 & - & 0.1 & 8.1 \\
\hline & Pig (live weight) & 67.2 & 1.5 & - & 3.7 & 27.6 \\
\hline & Milk & 99.1 & 0.7 & - & - & 0.2 \\
\hline \multirow{3}{*}{2014} & $\begin{array}{l}\text { Big cattle meat (live } \\
\text { weight) }\end{array}$ & 95.2 & 0.7 & - & - & 4.1 \\
\hline & Pig (live weight) & - & - & - & 57.6 & 42.4 \\
\hline & Milk & 99.5 & 0.3 & - & - & 0.2 \\
\hline \multirow{3}{*}{2016} & $\begin{array}{l}\text { Big cattle meat (live } \\
\text { weight) }\end{array}$ & 94.9 & 0.9 & - & 0.1 & 4.1 \\
\hline & Pig (live weight) & 86.7 & 1.9 & - & - & 11.4 \\
\hline & Milk & 99.6 & 0.2 & - & - & 0.2 \\
\hline
\end{tabular}

ers of Khrystynivka district made an attempt to sell pig through the local market and the neighboring markets. However, in the future, they gave up this idea, as additional expenses for bringing the products to the marketable condition and transportation costs were not compensated.

The ratio of individual channels of product sales varies slightly in the studied farms, but the price premium received by commodity producers is significantly different (Figure 1). This is explained not only by the differences in the quality parameters of the product and the different period of its sales, but also by the different volumes of batch of homogeneous products formed for sale and the existing contractual relations that are opaque in some cases.
The enterprisers of Khrystynivka district almost do not engage in the promotion of certain types of products on the market. This is due to the fact that, on the one hand, the demand for them is always present, and, on the other hand, they are produced, with similar parameters, by a large number of commodity producers, each of which has a small share in the market. Therefore, placing ads on batches of products for sale on specialized sites (for example, agro-ukraine.com/ua) is the most they do. As a rule, enterprises distribute information about themselves in various industry directories. Traditionally, they take part in local exhibitions (for example, for the Ukraine's Independence day) and Days of the Field. Some farms have their own sites on the Internet, but they themselves pay little attention to them (information is updated ir-



Figure 1. Difference in the sale prices for core products of agricultural enterprises of Khrystynivka district (2016 data) 
regularly; there is no special staff member whose responsibilities include the site maintenance, etc.). However, changing the market conditions and economic relations between its participants is a prerequisite for updating the marketing system of agrarian enterprises. The newest system is formed based on interactive technologies, in particular, selling agricultural products through the Internet. Advantages of using this system in marketing are reduced to the distribution channels optimization, sale costs reduction, increase in the level of sales performance, it also allows for maintaining relationships with regular consumers and attracting new customers, etc.

All agricultural enterprises in Khrystynivka district have no specialized divisions or individual posts whose duties would include the systematic performance of marketing functions. They are executed by farm managers and key specialists within their competence. Thus, the chief agronomist and the chief livestock expert are engaged in the formation of the product range for the coming year. The chief accountant is in charge of price formation and designing sales contracts, and chief engineer and storekeeper are responsible for logistics. Only the executive manager is engaged in communication as an element of the marketing complex. Thus, at the agricultural enterprises, the organizational structure does not meet the marketing principles, which is manifested in the complexity of the internal interaction of services and structural units, limited marketing tools for market analysis, and ineffective management.

Lack of a robust system of information support has a negative impact on the agricultural enterprises performance. Apart from the fact that there are no special employees responsible for collecting market information, there is virtually no software product for processing such data.

According to the Khrystynivka district employers survey, the vast majority of them are not engaged in strategic planning, limited to plans for one year only. They usually represent a production program for the specified period. Instead, the longterm perspective is not clearly expressed and manifests itself only fragmentarily (for example, the purchase of certain equipment samples). However, the introduction of strategic planning at these enterprises has the following advantages: this encourages management to be visionary; generates performance indicators for the next control; promotes a clearer definition of goals, objectives and ways to achieve them; adapts to sudden changes in the market environment; provides a clearer coordination of subdivisions by clearly defining the responsibilities of managers at all levels; contributes to a more efficient resource allocation; reduces the risks of loss of profits as a result of timely assessment and taking possible threats into account.

The size of the enterprise marketing costs determines the possibilities of finding the optimal (according to the price) product sales channel and forming a sound commodity policy in terms of the possibility of forecasting the price market conditions based on the use of information systems for processing marketing information. Consequently, effective marketing costs make it possible to increase profits. But not all marketing costs are effective. In addition, their growth can reduce profits in the short run due to the growth of full cost of production. The connection between the marketing expenses of agricultural enterprises in Khrystynivka district and the volume of their profit can be checked through a simple linear regression model:

$$
y=\beta_{0}+\beta_{1} x+\varepsilon,
$$

where $y$ - dependent variable (profit of enterprises), $x$ - independent variable (marketing costs), $\beta_{0}-$ regression intersection, $\beta_{1}-$ regression slope, $\varepsilon$-accidental variable.

The relationship between the volume of marketing costs and the profit margin of agricultural enterprises in Khrystynivka district is shown in Figure 2. In order to obtain a more reliable regression dependence equation, data for 10 years (2007-2016) were taken.

Given that the trend line is increasing (see Figure 2), there is a positive linear dependence between the parameters analyzed. Consequently, the volume of marketing costs affects the profit of the investigated agricultural enterprises. Proceeding from the obtained equation, in the absence of marketing costs, enterprises will suffer losses. Using Microsoft Excel and the Data Analysis Addin, Table 7 presents the regression statistics results. 




Figure 2. Correlation-regression dependence between the volume of marketing expenses and the profit margin of agricultural enterprises in Khrystynivka district,

Cherkasy region (according to 2007-2016 data)

According to Table 7, the determination coefficient is 0.733241 or $73.3 \%$. Accordingly, profit growth of $73.3 \%$ is associated with an increase in marketing costs of enterprises. Since the obtained value of significance $F(0,001562931)$ is significantly less than 0.05 , the model is significant.

The size of marketing costs accounting for individual products depends on their sales. Table 8 gives information on the share of marketing costs in full cost of production. On average, they occupy about $10 \%$ of households. However, in the field of crop production, the indicator was slightly higher than that of livestock production. Considering them in terms of product types and individual years, one should note its instability, which is related, first of all, to the qualitative parameters of the products and their compliance with the normative values given in the standards.

Table 7. Regression analysis results of the relationship between the marketing costs and the profit margin of agricultural enterprises in Khrystynivka district, Cherkasy region (according to 2007-2016 data)

\begin{tabular}{|c|c|c|c|c|c|c|c|c|c|c|c|}
\hline \multicolumn{12}{|c|}{ Regression statistics } \\
\hline \multicolumn{2}{|c|}{ Multiple R } & \multicolumn{4}{|c|}{ R-squared } & \multicolumn{2}{|c|}{$\begin{array}{c}\text { Standardized } \\
\text { R-squared }\end{array}$} & \multicolumn{2}{|c|}{ Standard error } & \multicolumn{2}{|c|}{$\begin{array}{c}\text { Number of } \\
\text { observations }\end{array}$} \\
\hline \multicolumn{2}{|c|}{0.856295} & \multicolumn{4}{|c|}{0.733241} & \multicolumn{2}{|r|}{0.6998958} & \multicolumn{2}{|r|}{31372.68} & \multicolumn{2}{|r|}{10} \\
\hline \multicolumn{12}{|c|}{ ANOVA } \\
\hline \multicolumn{2}{|c|}{ Degrees of freedom } & \multicolumn{2}{|c|}{ df } & \multicolumn{2}{|c|}{ SS } & \multicolumn{2}{|r|}{ MS } & \multicolumn{2}{|l|}{$\mathbf{F}$} & \multicolumn{2}{|c|}{ F significance } \\
\hline \multicolumn{2}{|l|}{ Regression } & \multicolumn{2}{|c|}{1} & \multicolumn{2}{|c|}{21643140416} & \multicolumn{2}{|c|}{21643140416} & \multicolumn{2}{|c|}{21.98959013} & \multicolumn{2}{|c|}{0.001562931} \\
\hline \multicolumn{2}{|l|}{ Residual } & \multicolumn{2}{|c|}{8} & \multicolumn{2}{|c|}{7873958647} & \multicolumn{2}{|c|}{984244830.8} & \multicolumn{2}{|l|}{-} & \multicolumn{2}{|l|}{-} \\
\hline \multicolumn{2}{|l|}{ Total } & \multicolumn{2}{|c|}{9} & \multicolumn{2}{|c|}{29517099062} & & - & \multicolumn{2}{|l|}{ - } & \multicolumn{2}{|l|}{-} \\
\hline $\begin{array}{l}\text { Degrees } \\
\text { of freedom }\end{array}$ & \multicolumn{2}{|c|}{ Coefficients } & & $\begin{array}{l}\text { ndard } \\
\text { rror }\end{array}$ & \multicolumn{2}{|c|}{ t-statistics } & P-value & $95 \%$ under & $95 \%$ upper & $95 \%$ under & $95 \%$ upper \\
\hline$\beta_{0}$ & \multicolumn{2}{|c|}{-42396.6} & 211 & 48.4573 & -2.004 & 1325 & 0.0799304 & -91165.023 & 6371.837 & -91165.023 & 6371.837 \\
\hline$\beta_{1}$ & 4.88189 & & 1.04 & 106993 & 4.689 & 593 & 0.0015629 & 2.481 & 7.283 & 2.48118383 & 7.2826069 \\
\hline
\end{tabular}


Table 8. Share of marketing expenditures in full cost of sold agricultural products of Khrystynivka district, Cherkasy region

Source: Calculated according to the data of agricultural enterprises' reporting.

\begin{tabular}{|c|c|c|c|c|c|}
\hline Index & 2012 & 2013 & 2014 & 2015 & 2016 \\
\hline Marketing expenditures, total & 10.2 & 9.2 & 9.8 & 9.2 & 8.7 \\
\hline Including crop production: & 10.7 & 7.5 & 8.3 & 8.9 & 10.1 \\
\hline - wheat & 14.0 & 11.1 & 9.7 & 9.1 & 10.0 \\
\hline - grain maize & 8.2 & 5.4 & 10.5 & 7.7 & 10.5 \\
\hline - barley & 13.7 & 9.5 & 9.9 & 10.8 & 8.0 \\
\hline - $\quad$ sunflower seeds & 10.5 & 7.0 & 5.9 & 9.4 & 10.5 \\
\hline - soy & 11.6 & 6.2 & 6.3 & 10.7 & 6.9 \\
\hline - $\quad$ rape plant & 11.4 & 11.6 & 9.8 & 7.3 & 14.5 \\
\hline Livestock production: & 9.5 & 11.7 & 11.8 & 10.1 & 6.3 \\
\hline - live weight of big cattle & 12.3 & 13.3 & 8.4 & 15.4 & 6.8 \\
\hline - $\quad$ live weight of pigs & 18.3 & 9.7 & 10.4 & 12.0 & 11.3 \\
\hline - $\quad$ milk & 7.0 & 8.0 & 12.6 & 8.6 & 6.1 \\
\hline
\end{tabular}

The amount of profit is, first of all, an indicator of the agricultural enterprises efficiency. In general, in terms of the enterprises under study, on average for the period $2012-2016$, about $93 \%$ of products belong to the crop production (Table 9). From the given index, $44 \%$ are accounted for sunflower seeds, $27.5 \%$ for grain maize, and $12.6 \%$ for winter wheat. The most unprofitable categories of product range of farms belong to the livestock sector, namely the live weight of cattle and other livestock products $(-8.7 \%$ and $3.9 \%$, respectively), but they are covered by the proceeds from the sale of milk (20.3\%), which ensures a positive level of the industry efficiency as a whole.

Table 9. Dynamics and distribution of profit received by agricultural enterprises of Khrystynivka district, Cherkasy region (by types of products)

Source: Compiled according to the Statistical Yearbook of Ukraine data.

\begin{tabular}{|c|c|c|c|c|c|c|c|}
\hline \multirow{2}{*}{ Products } & \multirow{2}{*}{2012} & \multirow{2}{*}{2013} & \multirow{2}{*}{2014} & \multirow{2}{*}{2015} & \multirow{2}{*}{2016} & \multicolumn{2}{|c|}{ 5-year average } \\
\hline & & & & & & UAH thou & $\%$ \\
\hline Crop production, total & $22,683.9$ & $13,825.3$ & $37,919.4$ & $132,249.6$ & $144,809.1$ & $70,297.5$ & 93.05 \\
\hline Cereals & $8,948.5$ & $10,007.0$ & $13,830.8$ & $74,683.3$ & $56,994.2$ & $32,892.8$ & 43.54 \\
\hline Including wheat & $3,080.1$ & 953.2 & $3,715.4$ & $26,596.3$ & $13,220.0$ & $9,513.0$ & 12.59 \\
\hline Rye & 67.4 & -12.0 & 0.0 & 0.0 & 9.0 & 12.9 & 0.02 \\
\hline Buckwheat & 20.0 & -40.0 & 15.0 & 264.0 & 50.0 & 61.8 & 0.08 \\
\hline Grain maize & $4,323.3$ & $9,035.4$ & $8,520.2$ & $40,880.0$ & $40,985.6$ & $20,748.9$ & 27.46 \\
\hline Barley & $1,566.1$ & -72.6 & $1,415.5$ & $6,857.0$ & $2,019.6$ & $2,357.1$ & 3.12 \\
\hline Pea & 48.6 & 132.0 & 149.0 & 86.0 & 701.0 & 223.3 & 0.30 \\
\hline Oil crops & $13,269.1$ & $4,044.2$ & $23,875.1$ & $57,179.2$ & $87,275.0$ & $37,128.5$ & 49.15 \\
\hline Sunflower seeds & $11,204.1$ & $2,788.6$ & $18,040.9$ & $52,017.7$ & $78,195.5$ & $32,449.4$ & 42.95 \\
\hline Rape plant & $2,191.0$ & 803.7 & $3,028.2$ & $4,232.5$ & $4,513.5$ & $2,953.8$ & 3.91 \\
\hline Soy & -126.0 & 451.9 & $2,806.0$ & 929.0 & $4,566.0$ & $1,725.4$ & 2.28 \\
\hline Sugar beet & -70.0 & 0.0 & 0.0 & 0.0 & 65.0 & -1.0 & 0.00 \\
\hline Field vegetables & 269.0 & 143.0 & 270.0 & -186.0 & -260.0 & 47.2 & 0.06 \\
\hline Fruit & 114.0 & -66.0 & -44.1 & -14.4 & -33.2 & -8.7 & -0.01 \\
\hline Other crop products & 153.3 & -302.9 & -12.4 & 587.5 & 768.1 & 238.7 & 0.32 \\
\hline Livestock, total & $-2,314.4$ & $-5,052.2$ & $8,598.1$ & $12,093.1$ & $12,942.4$ & $5,253.4$ & 6.95 \\
\hline Big cattle meat (live weight) & $-5,221.0$ & $-7,194.5$ & $-9,235.7$ & $-2,530.3$ & $-8,545.4$ & $-6,545.4$ & -8.66 \\
\hline Pig (live weight) & $-1,304.0$ & $-1,515.0$ & -235.0 & 6.0 & 118.0 & -586.0 & -0.78 \\
\hline Milk & $5,442.3$ & $10,949.9$ & $19,408.2$ & $17,265.2$ & $23,563.2$ & $15,325.8$ & 20.29 \\
\hline Other livestock products & $-1,231.7$ & $-7,292.6$ & $-1,339.4$ & $-2,647.8$ & $-2,193.4$ & $-2,941.0$ & -3.89 \\
\hline Services & 5.0 & -142.4 & -110.9 & -1.4 & 233.9 & -3.2 & 0.00 \\
\hline Total & $20,374.5$ & $8,630.7$ & $46,406.6$ & $144,341.3$ & $157,985.4$ & $75,547.7$ & 10,000 \\
\hline
\end{tabular}


Table 10. Marketing performance of agricultural enterprises in Khrystynivka district, Cherkasy region

\begin{tabular}{|c|c|c|c|c|c|}
\hline Index & 2012 & 2013 & 2014 & 2015 & 2016 \\
\hline \multicolumn{6}{|c|}{ For enterprises totally } \\
\hline Cash flow, UAH thou & $24,621.2$ & $15,175.5$ & $55,335.9$ & $154,729.3$ & $169,153.1$ \\
\hline Marketing costs for $\mathrm{UAH} 1,000$ of commodity products & 92.81 & 88.32 & 80.41 & 66.24 & 61.42 \\
\hline Net profit coefficient & 0.1 & 0.04 & 0.22 & 0.39 & 0.42 \\
\hline Coefficient of production and marketing efficiency & 0.084 & 0.031 & 0.158 & 0.365 & 0.331 \\
\hline \multicolumn{6}{|c|}{ Crop production } \\
\hline Cash flow, UAH thou & $24,446.9$ & $16,435.9$ & $42,150.1$ & $137,410.8$ & $150,833.4$ \\
\hline Marketing costs for $\mathrm{UAH} 1,000$ of commodity products & 90.88 & 68.60 & 63.09 & 59.07 & 63.11 \\
\hline Net profit coefficient & 0.17 & 0.10 & 0.32 & 0.51 & 0.60 \\
\hline Coefficient of production and marketing efficiency & 0.164 & 0.086 & 0.212 & 0.505 & 0.464 \\
\hline \multicolumn{6}{|c|}{ Livestock production } \\
\hline Cash flow, UAH thou & 169.3 & $-1,118$ & $13,296.7$ & $17,319.9$ & $18,085.8$ \\
\hline Marketing costs for $U A H 1,000$ of commodity products & 98.22 & 124.06 & 107.72 & 90.90 & 57.72 \\
\hline Net profit coefficient & -0.16 & -0.05 & 0.09 & 0.11 & 0.10 \\
\hline Coefficient of production and marketing efficiency & -0.022 & -0.044 & 0.074 & 0.090 & 0078 \\
\hline
\end{tabular}

During the period 2012-2016, the indicator of marketing performance of Khrystynivka district farms increased almost three times (Table 10). The size of the cash flow, representing the amount of profits and depreciation, increased more than five times, but the growth of sales prices under the influence of inflationary processes in the country was the main factor. Such rapid growth has led to reducing marketing costs in the amount of UAH 1,000 (by $33.9 \%$ ). Another factor was the reduction of enterprise costs to find the most attractive channels for product distribution and promotion. Positive trends in the marketing performance indicators are observed in the field of crop and livestock production. However, these are averaged data. The variability of these relative indicators for individual economic entities for 2016 is as follows: marketing costs for 1,000 UAH of commodity products $-27.5 \%$; the coefficient of production and marketing efficiency $-42.3 \%$.

The above indicators will be analyzed in terms of types of farm products (Table 11). Table 11 indicates that the highest marketing performance is observed in the core products for crop enterprises: grain maize and sunflower seeds. As for the livestock sector, milk is the undisputed leader. Calculations show that in the crop production, the variability of the marketing performance indices in some agricultural enterprises of Khrystynivka district, Cherkasy region, is much higher than in livestock production. This is due to the greater variation of the channels used by individual farms to sell crop products, significant differences in its qualitative parameters and, accordingly, the cost of bringing to the market standards.

The analysis of features and assessment of the marketing performance of farms in Khrystynivka district of Cherkasy region suggest that it is impossible to significantly improve its efficiency in the short term at the level of an individual enterprise. To form a robust marketing strategy and to implement all marketing complex functions, it is necessary, first of all, to attract competent marketers who will require appropriate remuneration. But only individual large farms' managers are able to afford such extra costs and consider them feasible. According to the 2017 poll results, only three out of 18 executives are ready to recruit one highly skilled expert. The other respondents consider it inexpedient to introduce an additional staffing unit and rely on their own experience in shaping and implementing a business strategy.

Given that the products are relatively standardized and the product market is competitive, most managers consider the price of commodity products as a market given value at each specific moment of time, and the essence of their pricing policy is reduced to the choice of the most favorable moment of implementation (if possible, the preservation of the product without losing its qualitative characteristics). With regard to the product distribution policy, as already noted, the channels for 
Table 11. Marketing performance of agricultural enterprises of Khrystynivka district, Cherkasy region in terms of products

Source: Calculated according to the data of agricultural enterprises' reporting.

\begin{tabular}{|c|c|c|c|c|c|}
\hline Index & 2012 & 2013 & 2014 & 2015 & 2016 \\
\hline \multicolumn{6}{|c|}{ Wheat } \\
\hline Cash flow, UAH thou & $3,438.5$ & $1,305.2$ & $4,688.5$ & $27,613.1$ & $14,052.0$ \\
\hline Marketing costs for UAH 1,000 of commodity products & 124.98 & 106.64 & 85.07 & 59.45 & 77.05 \\
\hline Net profit coefficient & 0.12 & 0.04 & 0.14 & 0.53 & 0.29 \\
\hline Coefficient of production and marketing efficiency & 0.104 & 0.035 & 0.105 & 0.526 & 0.259 \\
\hline \multicolumn{6}{|c|}{ Grain maize } \\
\hline Cash flow, UAH thou & $4,652.7$ & $9,493.5$ & $9,567.1$ & $41,735.7$ & $42,479.6$ \\
\hline Marketing costs for $\mathrm{UAH} 1,000$ of commodity products & 75.84 & 47.19 & 78.66 & 54.85 & 63.03 \\
\hline Net profit coefficient & 0.08 & 0.15 & 0.34 & 0.41 & 0.67 \\
\hline Coefficient of production and marketing efficiency & 0.130 & 0.202 & 0.204 & 0.558 & 0.534 \\
\hline \multicolumn{6}{|c|}{ Barley } \\
\hline Cash flow, UAH thou & $1,746.4$ & 247.7 & $1,622.1$ & $7,208.5$ & $2,439.4$ \\
\hline Marketing costs for UAH 1,000 of commodity products & 115.27 & 95.57 & 81.33 & 68.12 & 67.14 \\
\hline Net profit coefficient & 0.19 & -0.01 & 0.22 & 0.59 & 0.19 \\
\hline Coefficient of production and marketing efficiency & 0.131 & -0.007 & 0.157 & 0.518 & 0.132 \\
\hline \multicolumn{6}{|c|}{ Sunflower seeds } \\
\hline Cash flow, UAH thou & $11,458.2$ & $3,219.9$ & $19,037.5$ & $53,022.0$ & $79,738.1$ \\
\hline Marketing costs for $U A H 1,000$ of commodity products & 75.30 & 65.08 & 41.41 & 54.35 & 57.97 \\
\hline Net profit coefficient & 0.40 & 0.08 & 0.42 & 0.72 & 0.81 \\
\hline Coefficient of production and marketing efficiency & 0.508 & 0.107 & 0.548 & 0.920 & 1.036 \\
\hline \multicolumn{6}{|c|}{ Big cattle (live weight) } \\
\hline Cash flow, UAH thou & $-5,017.4$ & $-7,025.5$ & $-8,536.4$ & $-1,829.4$ & $-7,526.7$ \\
\hline Marketing costs for UAH 1,000 of commodity products & 188.37 & 240.69 & 149.96 & 171.88 & 99.99 \\
\hline Net profit coefficient & -0.35 & -0.45 & -0.44 & -0.11 & -0.33 \\
\hline Coefficient of production and marketing efficiency & -0.220 & -0.282 & -0.302 & -0.073 & -0.210 \\
\hline \multicolumn{6}{|c|}{ Pigs (live weight) } \\
\hline Cash flow, UAH thou & $-1,115.1$ & $-1,515.0$ & -232 & 50 & 118 \\
\hline Marketing costs for UAH 1,000 of commodity products & 206.71 & 135.67 & 200.79 & 119.40 & 79.08 \\
\hline Net profit coefficient & -0.12 & -0.29 & -0.48 & 0.01 & 0.43 \\
\hline Coefficient of production and marketing efficiency & -0.104 & -0.407 & -0.259 & 0.006 & 0.074 \\
\hline \multicolumn{6}{|c|}{ Milk } \\
\hline Cash flow, UAH thou & $6,188.4$ & $13,831.0$ & $23,384.9$ & $21,677.8$ & $27,631.2$ \\
\hline Marketing costs for UAH 1,000 of commodity products & 63.15 & 67.87 & 98.58 & 70.26 & 49.63 \\
\hline Net profit coefficient & 0.11 & 0.18 & 0.28 & 0.22 & 0.23 \\
\hline Coefficient of production and marketing efficiency & 0.095 & 0.160 & 0.247 & 0.190 & 0.204 \\
\hline
\end{tabular}

the implementation of core products vary slightly in farms, but the sale costs vary considerably over the same channels, depending on the batch size and the implementation time.

While forming the commodity policy, marketing research is reduced mainly to a retrospective monitoring of market conditions for core agricultural products, which the farm produces, or can potentially produce, taking climatic conditions into account.
While shaping a communicative policy, the preference is given to establishing effective links with local authorities and communities, as well as situational relations with material resource suppliers and intermediary entities.

Taking into account existing approaches to the organization of marketing activities of agricultural enterprises in Khrystynivka district, Cherkasy region, the creation of formal or informal associations of producers is the main direction of its improvement, 
which will significantly increase the marketing costs efficiency. In world and domestic practice, such associations operate on the basis of vertical or horizontal integration and are created on a functional (production, sales, service, etc.) or territorial basis. The purpose of their operation is more efficient use of resources and reduction of transaction costs for each participant. Formal associations are most often created as cooperatives, but in Ukraine, the co-operation process has not become widespread because of the following main reasons:

- compulsory participation of the cooperative members in the creation of the property, registration fees and share contributions in the amounts and terms specified in the statute. This reaffirms the fears and unwillingness of future cooperative members to invest in its creation and development;

- the principle of obligatory participation of cooperative members in the economic activity in the agreed volumes is violated. The cooperative members' unwillingness to produce certain products in certain volumes, because each producer tries to focus on the market environment that was formed at a given time;

- unwillingness of the cooperative members to meet the obligations of the cooperative in the part relating to the joint activity;

- violation of the democratic management, which is manifested in the cooperative chairman abuse by his authorities, in violation of the right to equal access to the use of services, in the information protection;

- violation of the pricing principles in cooperatives and timely settlements with cooperative members;

- inadequate qualification and experience of executive staff, small number of executive directors, lack of a separate marketing service, legal support, which results in poor cooperative's sales performance (Lohosha, 2017).

Taking these into account, the most likely to implement is the creation of an informal associa- tion of investigated enterprises in order to increase their marketing performance according to a functional and territorial principle. The territorial principle of association involves coordinating the agricultural enterprises' activities at the level of councils of the united territorial communities (UTC). In the context of the administrative and territorial reform implemented by the Ukrainian government, these structural units should receive the appropriate resource in the form of local tax revenues and be fully responsible for the social infrastructure of the territories, that is education, health care, services, etc. At the district level, only the community cooperation issues remain. Since in Ukraine a moratorium on free sale of agricultural lands is prolonged annually, one can expect that joint responsibility for the territory development will either lead to the gradual centralization of "effective" capital, that is, terminating contracts for the land lease for those agricultural enterprises that make the lowest tax payments in terms of one hectare in the UTC budget, or to forced coordination of their activities to obtain the maximum economic effect.

As of March 2018, there was no UTC created in Khrystynivka district. This is due to the presence of two views of local elites and officials as to the future administrative-territorial structure of the district. According to the first approach outlined in the perspective plan for the formation of the community territories of Cherkasy region, it is envisaged to create Khrystynivka UTC, which will include the city of Khrystynivka and five bordering villages. In this case, other territorial communities of the villages will be united with 2-3 nearest neighbors. Another point of view is defended by the current composition of the district council deputies. In their opinion, it is expedient to combine all the communities that are part of Khrystynivka district into one UTC. Regardless of which settlements between representatives of different communities as to the UTC creation are made, Ukrainian officials are planning to finish this stage of administrative and territorial reform in 2019. And those communities which until then are not unite voluntarily will be united forcibly (Sydorenko, 2017, 2018). Therefore, the UTC council will be the primary element to coordinate the activities of economic entities. 
Given the heterogeneity of agricultural enterprises by specialization, land area, and volumes of commodity production, the main functional feature of such an informal association in the initial stages can be only sales activity. This will allow individual independent economic entities to form larger batches of homogeneous products and sell them at higher prices, as well as to save on the cost of storage and transportation of products. That is, the main purpose of their activity is to reduce transaction costs and obtain an additional premium.

\section{CONCLUSION}

The study analyzes the main trends, management and managerial efficiency of marketing performance of agricultural enterprises in Ukraine, as exemplified by farms of Khrystynivka district, Cherkasy region. The analysis showed that, regardless of the farm size and its specialization, marketing activity is mainly limited to the formation of short-term commodity policy and distribution policy, the effectiveness of which is significantly limited by the irrelevance of marketing information about the main market parameters. Other elements of the marketing complex are used randomly and fragmentarily, increasing overall marketing costs and generating no additional revenue.

A correlation-regression analysis according to the 2007-2016 data indicates that there is a relationship between the marketing costs and the profit of agricultural enterprises in Khrystynivka district of Cherkasy region. The determination coefficient is 0.733241 , or $73.3 \%$. Accordingly, revenue growth of $73.3 \%$ is due to an increase in marketing costs of enterprises. For the period 2012-2016, the efficiency of production and marketing for all of the enterprises under study varied significantly with the general tendency of its absolute value growth. This is due to the growing fluctuations of world food prices and the national currency rate, to which enterprises can only situationally adapt in the absence of a long-term development strategy and monitoring and forecasting system of environmental factors. Also, the efficiency coefficient of production and marketing in the context of individual farms by the same types of products varied considerably.

An analysis of the marketing costs distribution at the level of individual farms has shown that a significant part of them is aimed at promoting those agricultural products, the production of which the enterprise is mainly specialized in. In terms of other products, which serve to diversify risks within the existing commodity portfolio, marketing costs are minimal, which significantly reduces the profit from their implementation. At the same time, for a number of other enterprises in the region, these products are the main ones and significant marketing costs are directed at their promotion, which allows to benefit more from their implementation. The research allows to assert that it is impossible to significantly increase the efficiency of marketing costs in the short term at the level of a separate agricultural enterprise of the district. The formation and participation in horizontally or vertically integrated formal and informal associations of market participants are the main directions to improve the marketing performance management of agricultural enterprises in the short term. According to domestic practice, formal associations have not become widespread for a number of reasons, the main of which are conflicts of interest of participants due to their desire to maximize their own cash flow at the other participants' expense. In terms of reducing transaction costs and obtaining an additional premium from the sale of commodity products, the creation of informal associations within the united territorial communities is the most effective method in the short term, since all economic entities registered in their territory take joint responsibility for its social development. Determining the direction of improving the marketing performance management of agricultural enterprises in the long term requires further research on the formation of an optimal structure of marketing costs according to the main marketing complex elements, depending on the predominant specialization of farms. 


\section{REFERENCES}

1. Agbo, M., Rousselière, D., \& Salanié, J. (2015). Agricultural marketing cooperatives with direct selling: A cooperativenon-cooperative game. Journal of Economic Behavior \& Organization, 109, 56-71. https://doi. org/10.1016/j.jebo.2014.11.003

2. Annie Royer (2008). The Emergence of Agricultural Marketing Boards Revisited: A Case Study in Canada. Canadian Journal of Agricultural Economics, 56, 509-522. https://doi.org/10.1111/j.17447976.2008.00144.x

3. Barrett, C. B., \& Mutambatsere, E. (2008). Marketing Boards. The new Palgrave dictionary of economics. In Lawrence E. Blume \& Steven N. Durlauf (Eds.) Marketing of Agricultural Products (2nd ed.). London: Palgrave Macmillan, Forthcoming. Retrieved from https://ssrn.com/abstract $=1142519$

4. Cadilhon, Jo, \& Dedieu, MarieSophie (2011, June). Commodity associations: a widespread tool for marketing chain management. Division of Statistics and Strategic Foresight - Strategic Foresight and Evaluation Analysis, 31. Retrieved from http:// agreste.agriculture.gouv.fr/IMG/ pdf_analyse311106anglais.pdf

5. Carillo, F., Caracciolo, F., \& Cembalo, L. (2017). Do durum wheat producers benefit of vertical coordination? Agricultural and Food Economics. https://doi. org/10.1186/s40100-017-0088-7

6. Chand, R. (2012). Development Policies and Agricultural Markets. Economic \& Political Weekly, 47(52), 53-63. Retrieved from https://www.epw.in/journal/2012/52/review-rural-affairsreview-issues/development-policies-and-agricultural-markets

7. Chemerys, V. A. (2015). Інноваційний розвиток інфраструктури аграрного ринку: регіональний контекст [Innovatsiinyi rozvytok infrastruktury ahrarnoho rynku: rehionalnyi kontekst] (352 p.). Lviv: Avers.

8. Ferreira, K. J., Goh, J., \& Valavi,
E. (2017, October). Intermediation in the Supply of Agricultural Products in Developing Economies (Harvard Business School Working Paper, No. 18-033). Retrieved from https://www.hbs.edu/ faculty/Publication\%20Files/18033_8fcdda05-0410-4a43-b3294e30d790ceab.pdf

9. Gallego-Alvarez, I., PradoLorenzo, J. M., RodríguezDomínguez, L., \& GarcíaSánchez, I. M. (2010). Are social and environmental practices a marketing tool?: Empirical evidence for the biggest European companies. Management Decision, 48(10), 1440-1455. https://doi. org/10.1108/00251741011090261

10. Humeniuk, Н. (2014). Проблеми і перспективи стандартизації сільськогосподарської продукції [Problemy i perspektyvy standartyzatsii silskohospodarskoi produktsii]. Standartyzatsiia: metodolohiia ta praktyka, 6, 18-21.

11. Kiruthiga, K., Karthi, R., \& Daisy, B. A. (2015, April). Agricultural Marketing - An Overview. International Journal of Scientific and Research Publications, 5(4), 2015. Retrieved from http://www. ijsrp.org/research-paper-0415/ ijsrp-p40135.pdf

12. Kohls, R. L., \& Uhl, J. N. (2002). Marketing of agricultural products (9th ed.) (544 p.). Prentice Hall.

13. Larina, Ya. S. (2008). Формування та механізми реалізації маркетингових стратегій в агропродовольчому підкомплексі АПК [Formuvannia ta mekhanizmy realizatsii marketynhovykh stratehii $v$ ahroprodovolchomu pidkompleksi] (336 p.). Kyiv: Presa Ukrainy.

14. Lohosha, R. V. (2017). Стан та перспективи розвитку сільськогосподарських обслуговуючих кооперативів в галузі овочівництва [Stan ta perspektyvy rozvytku silskohospodarskykh obsluhovuiuchykh kooperatyviv v haluzi ovochivnytstva]. Ekonomika. Finansy. Menedzhment: aktualni pytannia nauky i praktyky, 9, 74-86.

15. Meulenberg, M. T. G. (1986).
The evolution of agricultural marketing theory: towards better coordination with general marketing theory. Netherlands Journal of Agricultural Science, 34, 301-315. Retrieved from https://www.researchgate.net/ publication/40216176_The_evolution_of_agricultural_marketing_theory_towards_better_coordination_with_general_marketing_theory

16. Opara, L. U. (2003). Traceability in agriculture and food supply chain: A review of basic concepts, technological implications, and future prospects. Food, Agriculture \& Environment, 1(1), 101-106. Retrieved from https://pdfs. semanticscholar.org/4f63/2b6ec4 bd1ebdc53a0fcf295b1cd3800ed1 1e.pdf

17. Sarker, D., \& Ghosh, B. K. (2010). Milk Marketing under Cooperative and Non-Cooperative Marketing Channels: Evidence from West Bengal. Economic Annals, 55(187), 87-108. https://doi. org/10.2298/eka1087087s

18. Soloviov, I. O. (2008). Агромаркетинг: системна методологія, реалізація концепції [Ahromarketynh: systemna metodolohiia, realizatsia kontseptsii] (344 p.). Kherson: Oldi-Plus.

19. State Statistics Service of Ukraine (2018). Очікування сільськогосподарських підприємств щодо перспектив розвитку їх ділової активності за видами економічної діяльності (2015-2018) [Ochikuvannia silskohospodarskykh pidpryiemstv shchodo perspektyv rozvytku yikh dilovoi aktyvnosti za vydamy ekonomichnoi diialnosti (2015-2018)]. Retrieved from http://www.ukrstat.gov.ua/

20. Statistical Book (2016). Сільське господарство Черкащини. Головне управління статистики у Черкаській області 2017 [Silske hospodarstvo Cherkashchyny. Holovne upravlinnia statystyky u Cherkaskii oblasti 2017] (234 p.). 
21. Statistical Yearbook of

Ukraine (n.d.). Основні економічні показники роботи сільськогосподарських підприємств Черкащини в 2012 (2013, 2014, 2015, 2016) році: Статистичний щорічник 2013 (2014, 2015, 2016, 2017) [Osnovni ekonomichni pokaznyky roboty silskohospodarskykh pidpryiemstv Cherkashchyny v 2012 (2013, 2014, $2015,2016)$ rotsi: Statystychnyi shchorichnyk 2013 (2014, 2015, 2016, 2017)] (101 p.). Cherkasy.

22. Statistical Yearbook of Ukraine (n.d.). Реалізація продукції сільськогосподарських підприємств Черкащини в 2012 (2013, 2014, 2015, 2016) році: Статистичний щорічник 2013 $(2014,2015,2016,2017)$ [Realizatsiia produktsii silskohospodarskykh pidpryiemstv Cerkashchyny v 2012
(2013, 2014, 2015, 2016) rotsi:: Statystychnyi shchorichnyk 2013 $(2014,2015,2016,2017)]$ (124 p.). Cherkasy.

23. Stepanova, A. A., Horbas I. M., \& Davydova O. G. (2017). Practical aspects of strategic marketing management of agricultural enterprises (on the example of "MRIYA AGRO HOLDING"). Financial and Credit Activity: Problems of Theory and Practice, 2(23), 221-228. https://doi. org/10.18371/fcaptp.v2i23.95635

24. Sydorenko, S. (2017, December 27). Реформа, якої не уникнути Україні: 10 прикладів об’єднання громад у країнах Європи [Reforma, yakoi ne unyknuty: 10 prykladiv obiednannia hromad u krainakh Yevropy]. Yevropeiska Pravda.
Retrieved from https://www. eurointegration.com.ua/ articles/2017/12/27/7075538/

25. Sydorenko, S. (2018, February 5). Доведеться створити нову карту України: посланець Меркель та Зубко розкрили плани адмінреформи [Dovedetsia stvoryty novu kartu Ukrainy: poslanets Merkel ta Zubko rozkryly plany adminreformy]. Yevropeiska Pravda. Retrieved from https://www.eurointegration.com. ua/interview/2018/02/5/7077057/

26. Ulianchenko, Yu. O., \& Kosenko, A. V. (2014). Державна політика щодо розвитку інфраструктури аграрного ринку [Derzhavna polityka shchodo rozvytku infrastructury ahrarnoho rynku]. Aktualni Problemy Derzhavnoho Upravlinnia, 2, 27-34. 